\title{
ROOT MORPHOLOGY OF MAIZE LINES WITH CONTRASTING DROUGHT RESISTANCE UNDER THREE TOXIC LEVELS OF ALUMINUM
}

\author{
PAULO CÉSAR MAGALHÃES ${ }^{1}$, THIAGO CORRÊA DE SOUZA², \\ FERNANDO RODRIGO DE OLIVEIRA CANTÃO ${ }^{3}$ and FÁBIO ANDRADE PADILHA ${ }^{4}$
}

${ }^{1}$ Pesquisador, Embrapa Milho e Sorgo, Sete Lagoas, MG, Brasil, pcesar@cnpms.embrapa.br

${ }^{2}$ Doutor em Fisiologia Vegetal, Ufla, Lavras, MG, Brasil, thiagonepre@hotmail.com

${ }^{3}$ Mestre em Fisiologia Vegetal, University of Illinois at Urbana-Champaign, Urbana, IL, USA, fernandocantao@yahoo.com.br

${ }^{4}$ Mestrando em Ciências Agrárias, UFSJ (Campus Sete Lagoas), Sete Lagoas, MG, Brasil, fabio@cnpms.embrapa.br

Revista Brasileira de Milho e Sorgo, v.11, n.1, p. 35-48, 2012

\begin{abstract}
The aim of this work was to evaluate attributes of dry mass and root morphology characteristics in lines with contrasting drought resistance (two tolerant and two sensitive) from the Breeding Program of CNPMS (Maize and Sorghum National Research Center), under three levels of aluminum saturation (low, intermediate and high). A randomized blocks design was used, with two replications for each level of Al-saturation. Evaluations were performed at 14 and 28 days after sowing. Root morphology was assessed using the WinRhizo image analysis system. Significant differences were observed for dry matter attributes between lines, especially the sensitive ones. Concerning root morphology, the drought resistant lines presented higher total root length (RL), root surface area (SA), root volume $(\mathrm{RV})$ and greater very thin roots length (VTRL). In conclusion, lines selected for drought resistance can be indirectly selected for aluminum tolerance.
\end{abstract}

Key words: aluminum toxicity, dry mass, water deficit, WinRhizo, Zea mays L.

\section{MORFOLOGIA RADICULAR EM LINHAGENS DE MILHO CONTRASTANTES À SECA EM TRÊS NÍVEIS DE ALUMÍNIO}

RESUMO - O objetivo deste trabalho foi avaliar atributos de massa seca e características de morfologia radicular em linhagens contrastantes à seca (duas tolerantes e duas sensíveis) do Programa de Melhoramento do CNPMS (Centro Nacional de Pesquisa de Milho e Sorgo) sob três níveis de saturação de alumínio (baixo, intermediário e alto). O delineamento experimental utilizado foi o de blocos casualizados em esquema fatorial (quatro linhagens e três níveis de Al), com três repetições. A avaliação das características foi realizada 14 e 28 dias após a semeadura. Para a morfologia radicular, foi utilizado o programa de análise de imagens WinRhizo. Foram observadas diferenças significativas para os atributos de massa seca entre as linhagens, sendo mais acentuada nas linhagens sensíveis. Já na morfologia radicular, as linhagens tolerantes à seca apresentaram maiores comprimento total (CTR), área de superfície (ASR), volume (VR) e comprimento de raízes muito finas (CRMF). Conclui-se que linhagens selecionadas para tolerância à seca podem ser indiretamente selecionadas para tolerância ao alumínio.

Palavras-chave: toxidez por alumínio, massa seca, deficiência hídrica, WinRhizo, Zea mays L.

Versão impressa ISSN 1676-689X / Versão on line ISSN 1980-6477

http://www.abms.org.br 
Acid soils $(\mathrm{pH} \leq 5.5)$ and water deficit are some of the major limitations on agriculture (Tuberosa et al., 2007; Fan et al., 2009). Studies regarding drought tolerance in maize may lead to improvements in growth and yield of the crop in regions with water deficit (Li et al., 2009), since maize is known by its high sensitivity to this stress (Vamerali et al., 2003; Welcker et al., 2007). Moreover, material tolerant to this abiotic stress adds value to the seed for commercialization. In maize, the expansion of the root system to get underground water is one of the main characteristics responsible for tolerance (Hund et al., 2009).

Approximately $50 \%$ of the cultivable soils in the world are acid and present toxic aluminum (Al) levels (Kochian et al., 2004). In Brazil, acid soils are mainly found in the Cerrado region, occupying around 204 million hectares (Cançado et al., 2002).

When present in toxic levels in the soil, aluminum can cause harmful effects to plants, causing damages and delayed growth. Absorption and accumulation of this element in different parts of the plant affect cells and organelles at morphological, cytogenetical and physiological levels, reducing growth, particularly of the root system. Many studies have shown that restriction of root growth is the more rapidly visible symptom of Al toxicity in plants, resulting in the reduction and damage to the root system, and may cause mineral deficiency and water stress (Doncheva et al., 2005; Kochian et al., 2005; Farias et al., 2011). Studies carried out by Tamas et al., (2006) in barley found a gene linked to water deficit highly expressed under elevated aluminum concentrations. Okiyo et al. (2010) reported that crosses of sorghum genotypes tolerant to aluminum toxicity and drought-tolerant genotypes generated more productive progenies when subjected to these stresses simultaneously.

Studies have shown that growth of shoots under aluminum toxicity occurs later, possibly as a consequence of damages in roots. Aluminum toxicity can also cause inhibition or reduction in leaf photosynthetic parameters (Peixoto et al., 2002; Kochian et al., 2004; Kochian et al., 2005; Mihailovic et al., 2008).

From the knowledge that aluminum toxicity and water stress affect root morphology and that this is an essential feature in the search for tolerant maize genotypes (Haling et al., 2010; Trachsel et al., 2011), it was hypothesized that drought tolerant lines from the breeding program of CNPMS (Maize and Sorghum National Research Center) may also present mechanisms of tolerance to aluminum toxicity. Thus, the objective of the present work was to evaluate attributes of shoot and root dry mass and the root morphology of maize lines with contrasting drought tolerance in response to three levels of aluminum saturation.

\section{Material and Methods}

The experiment was carried out at CNPMS (Maize and Sorghum National Research Center ), in Sete Lagoas, Minas Gerais State, Brazil, located at $19^{\circ} 28^{\prime}$ latitude S, $44^{\circ} 15^{\prime} 08^{\prime \prime}$ longitude $\mathrm{W}$ and 732 $\mathrm{m}$ altitude. The climate is Aw type (savanna climate with dry winter).

Four lines from the breeding program of CNPMS were evaluated, with different genetic backgrounds and origin: two tolerant (L1 and L3) and two sensitive (L2 and L4) to drought. The lines were assessed in experimental seedbeds prepared 
separately for three different levels of aluminum saturation $(\mathrm{m} \%)$ : low $(\mathrm{m} \%=13)$, intermediate $(\mathrm{m} \%$ $=20)$ and high $(\mathrm{m} \%=60)$.

The seedbeds were $12.0 \mathrm{~m}$ long, $1.2 \mathrm{~m}$ wide and $0.4 \mathrm{~m}$ deep, under shade-net $50 \%$ and red-dark latosol, medium texture (Santos et al., 2006). The spatial variability of seedbeds regarding nutrient availability was verified through soil analysis. Plots were divided into six $2 \mathrm{~m}$ long sub-plots from which six simple samples were taken comprising a composite soil sample which was analyzed at the Laboratory of Soil Fertility. The results of chemical analysis of soil are shown in Table 1. at 14 and 21 days after sowing. Three plants were collected per plot, per replication, totaling six replications per genotype per evaluation time. After washed, plants were separated into shoots and roots. The following characteristics were evaluated: root dry mass (RDM), shoot dry mass (SDM), total dry mass (TDM) and RDM/SDM ratio. The plant material was stored in paper bags and placed into a forced ventilation oven at $72{ }^{\circ} \mathrm{C}$ until it reached constant mass.

The analysis system WinRhizo Pro 2007a (Régent Instr. Inc.) was used to evaluate root system morphology, connected to a professional scanner

TABLE 1. Chemical characteristics of soil (layer of $0-20 \mathrm{~cm}$ ).

\begin{tabular}{lccc}
\hline \multirow{2}{*}{ Parameters } & \multicolumn{3}{c}{ Level of Al } \\
\cline { 2 - 4 } & High & Intermediate & Low \\
\hline $\mathrm{pH}\left(\mathrm{H}_{2} \mathrm{O}\right)$ & 4.93 & 5.46 & 5.61 \\
$\mathrm{H}+\mathrm{Al}\left(\mathrm{cmolc} \mathrm{dm}^{3}\right)$ & 9.70 & 5.95 & 5.66 \\
$\mathrm{Al}\left(\mathrm{cmolc} \mathrm{dm}^{3}\right)$ & 1.84 & 0.67 & 0.52 \\
$\mathrm{Ca}\left(\mathrm{cmolc} \mathrm{dm}^{3}\right)$ & 0.94 & 2.12 & 2.82 \\
$\mathrm{Mg}\left(\mathrm{cmolc} \mathrm{dm}^{3}\right)$ & 0.12 & 0.24 & 0.45 \\
$\mathrm{~K}\left(\mathrm{mg} \mathrm{dm}^{3}\right)$ & 69.67 & 91.92 & 85.53 \\
$\mathrm{P}\left(\mathrm{mg} \mathrm{dm}^{3}\right)$ & 13.57 & 10.88 & 15.77 \\
$\mathrm{SB}\left(\mathrm{cmolc} \mathrm{dm}^{3}\right)$ & 1.24 & 2.60 & 3.49 \\
$\mathrm{CTC}\left(\mathrm{cmolc} \mathrm{dm}^{3}\right)$ & 10.94 & 8.56 & 9.15 \\
$\mathrm{~V}(\%)$ & 11.46 & 30.51 & 38.16 \\
$\mathrm{~m}(\%)$ & 59.71 & 20.69 & 13.00 \\
\hline
\end{tabular}

The experimental unit consisted of four $1.2 \mathrm{~m}$ long lines and five plants per linear meter, corresponding to 20 plants per genotype. A randomized blocks experimental design was used, with two replications (seedbeds) for each aluminum level.

Evaluation of characteristics of shoots and root system morphology were accomplished
Epson XL 10000 with additional light unit (TPU). A definition of 400 dpi was used to obtain the images of root morphology (Bouma et al., 2000). Roots were disposed in an acrylic container of $20 \mathrm{~cm}$ wide and 30 $\mathrm{cm}$ length with a water layer of one $\mathrm{cm}$ approximately and placed on the scanner. The following root characteristics were analyzed: total length $(\mathrm{TL}, \mathrm{cm})$, 
surface area $\left(\mathrm{SA}, \mathrm{cm}^{2}\right)$, volume $\left(\mathrm{RV}, \mathrm{cm}^{3}\right)$ average diameter $\left(\mathrm{ARD}, \mathrm{mm}^{2}\right)$ and root length per diameter class $(\mathrm{cm})$. Root length was classified according to three diameters, as follows: very thin roots length (VTRL) (less than $0.5 \mathrm{~mm}$ ), thin roots length (TRL) $(>0.5 \varnothing<2.0 \mathrm{~mm}$ ) and thick roots length (THRL) $(\varnothing>2.0 \mathrm{~mm})$ (Bhom, 1979). Other attributes were evaluated, such as: specific root length (root length/ root dry mass ratio) (SRL, $\mathrm{cm} \mathrm{g}^{-1}$ ) and root length/ shoot dry mass ratio (RL/SDM, $\left.\mathrm{cm} \mathrm{g}^{-1}\right)$. The results were subjected to analysis of variance ( $\mathrm{F}$ test), and means of treatments compared by Scott-Knott test at $5 \%$ probability.

\section{Results and Discussion}

\section{Dry mass production}

Production of root dry mass (RDM) did no differ significantly between genotypes and levels of aluminum saturation at 14 days after seeding (DAS) (Table 2). Nevertheless, shoot dry mass (SDM) and total dry mass (TDM) presented significant differences between genotypes only for the intermediate level of aluminum saturation, especially the drought sensitive lines (Table 2). Among levels of aluminum saturation significant differences were observed for SDM and TDM, with saturation levels low and high presenting the higher means. On average, drought sensitive lines presented the higher productions of SDM. Regarding root dry mass/shoot dry mass ratio, no significant differences were observed between genotypes and aluminum saturation levels at 14 DAS (Table 2).

Table 3 shows significant differences at 28 DAS between levels of aluminum saturation for RDM, TDM and RDM/SDM ratio where the highest saturation levels caused the highest reduction in RDM, TDM and RDM/SDM ratio. No difference between levels was observed for SDM. On average, both drought sensitive genotypes (L2 and L4) presented the highest values for root dry mass (RDM) and total dry mass (TDM), and the drought sensitive genotype L4 presented the highest mean for shoot dry mass (SDM) (Table 3).

Between genotypes, no difference occurred for RDM at any level. Production of SDM presented differences between genotypes at low and intermediate levels of aluminum saturation, and the drought-sensitive L4 line showed results significantly superior to the other lines evaluated. TDM production presented differences between genotypes only at the intermediate level of aluminum saturation, with the two sensitive lines significantly superior (Table 3 ).

An important fact observed for dry mass attributes was that drought sensitive lines (L2 and L4) presented, on average, greater dry mass accumulation than tolerant lines (L1 and L3) (Tables 2 and 3). Studies in soybean and barley showed that despite the excess of aluminum results in a reduction in the attributes of root dry mass, genotypes tolerant to this condition present higher dry mass compared to sensitive genotypes (Ali et al., 2011; Yu et al., 2011).

No significant difference was observed between genotypes regarding $\mathrm{RDM} / \mathrm{SDM}$ ratio, but at 28 days after sowing (DAS), as shown in Table 3 , the higher level of aluminum saturation caused lower shoot dry mass (SDM) and RDM/SDM ratio, corroborating the theory that the effect of $\mathrm{Al}$ is more pronounced in roots than in shoots (Kochian et al., 2005). According to Horn et al. (2006), the $\mathrm{RDM} / \mathrm{SDM}$ ratio is an important parameter for the evaluation of genotypes under different levels of aluminum saturation, because a high RDM/SDM is advantageous in conditions of low availability of nutrients and water in the soil. 
TABLE 2. Dry mass production in roots (RDM) shoots (SDM), total (TDM) and RDM/SDM ratio of maize genotypes in response to different levels of aluminum saturation, at 14 days after sowing.

\begin{tabular}{|c|c|c|c|c|}
\hline \multirow[t]{2}{*}{ Genotypes $^{1}$} & \multicolumn{3}{|c|}{ Level of Al } & \multirow[t]{2}{*}{ Mean } \\
\hline & Low & Intermediate & High & \\
\hline \multicolumn{5}{|c|}{ RDM $\left(\right.$ g plant $\left.^{-1}\right)$} \\
\hline L1 (T) & $6.58 \mathrm{~A}$ & $4.13 \mathrm{~A}$ & $8.80 \mathrm{~A}$ & $6.50 \mathrm{~A}$ \\
\hline L2 (S) & $7.42 \mathrm{~A}$ & $7.91 \mathrm{~A}$ & $5.89 \mathrm{~A}$ & $7.07 \mathrm{~A}$ \\
\hline $\mathrm{L} 3(\mathrm{~T})$ & $6.02 \mathrm{~A}$ & $4.60 \mathrm{~A}$ & $6.99 \mathrm{~A}$ & $5.87 \mathrm{~A}$ \\
\hline L4 (S) & $6.31 \mathrm{~A}$ & $6.79 \mathrm{~A}$ & $7.32 \mathrm{~A}$ & $6.81 \mathrm{~A}$ \\
\hline Mean & $6.58 \mathrm{a}$ & $5.86 \mathrm{a}$ & $7.25 \mathrm{a}$ & \\
\hline \multicolumn{5}{|c|}{ SDM $\left(\right.$ g plant $\left.^{-1}\right)$} \\
\hline $\mathrm{L} 1(\mathrm{~T})$ & $8.33 \mathrm{~A}$ & $7.94 \mathrm{~B}$ & $9.17 \mathrm{~A}$ & $8.48 \mathrm{~B}$ \\
\hline L2 (S) & $9.45 \mathrm{~A}$ & $9.33 \mathrm{~A}$ & $9.26 \mathrm{~A}$ & $9.35 \mathrm{~A}$ \\
\hline L3 (T) & $8.74 \mathrm{~A}$ & $7.60 \mathrm{~B}$ & $8.23 \mathrm{~A}$ & $8.19 \mathrm{~B}$ \\
\hline L4 (S) & $8.93 \mathrm{~A}$ & $8.22 \mathrm{~A}$ & $9.83 \mathrm{~A}$ & $8.99 \mathrm{~A}$ \\
\hline Mean & $8.86 \mathrm{a}$ & $8.27 \mathrm{~b}$ & $9.12 \mathrm{a}$ & \\
\hline \multicolumn{5}{|c|}{ TDM $\left(\right.$ g plant $\left.^{-1}\right)$} \\
\hline L1 (T) & $4.95 \mathrm{~A}$ & $4.05 \mathrm{~B}$ & $6.00 \mathrm{~A}$ & $5.00 \mathrm{~A}$ \\
\hline L2 (S) & $5.65 \mathrm{~A}$ & $5.75 \mathrm{~A}$ & $5.05 \mathrm{~A}$ & $5.48 \mathrm{~A}$ \\
\hline $\mathrm{L} 3(\mathrm{~T})$ & $4.95 \mathrm{~A}$ & $4.05 \mathrm{~B}$ & $5.10 \mathrm{~A}$ & $4.70 \mathrm{~A}$ \\
\hline L4 (S) & $5.10 \mathrm{~A}$ & $5.00 \mathrm{~A}$ & $5.70 \mathrm{~A}$ & $5.27 \mathrm{~A}$ \\
\hline Mean & $5.16 \mathrm{a}$ & $4.71 \mathrm{~b}$ & $5.46 \mathrm{a}$ & \\
\hline \multicolumn{5}{|c|}{$\mathrm{RDM} / \mathrm{SDM}$} \\
\hline L1 (T) & $0.79 \mathrm{~A}$ & $0.52 \mathrm{~A}$ & $0.96 \mathrm{~A}$ & $0.76 \mathrm{~A}$ \\
\hline L2 (S) & $0.78 \mathrm{~A}$ & $0.84 \mathrm{~A}$ & $0.63 \mathrm{~A}$ & $0.76 \mathrm{~A}$ \\
\hline $\mathrm{L} 3(\mathrm{~T})$ & $0.69 \mathrm{~A}$ & $0.60 \mathrm{~A}$ & $0.86 \mathrm{~A}$ & $0.72 \mathrm{~A}$ \\
\hline L4 (S) & $0.70 \mathrm{~A}$ & $0.82 \mathrm{~A}$ & $0.75 \mathrm{~A}$ & $0.76 \mathrm{~A}$ \\
\hline Mean & $0.74 \mathrm{a}$ & $0.70 \mathrm{a}$ & $0.79 \mathrm{a}$ & \\
\hline
\end{tabular}

${ }^{1}$ Means followed by the same capital letter in vertical and lowercase letter in horizontal did not differ significantly by Scott-Knott test at 5\%; S - drought sensitive, T - drought tolerant.

\section{Root Morphology}

No significant difference was observed among the levels of aluminum saturation for root length $(\mathrm{RL})$ at 14 and 28 days after seeding (DAS) (Table 4). On average, tolerant lines (L1 and L3) presented higher total length (TL) at 14 and 28 DAS. Difference was observed between genotypes at 14 DAS but only under the high level of aluminum saturation, with tolerant lines also presenting higher TL. At 28 DAS all levels caused significant differences between lines. 
TABLE 3. Roots dry mass production (RDM), shoots (SDM), total (TDM) and RDM/SDM ratio of maize genotypes in response to different levels of aluminum saturation, at 28 days after sowing.

\begin{tabular}{|c|c|c|c|c|}
\hline \multirow[t]{2}{*}{ Genotypes } & \multicolumn{3}{|c|}{ Level of Al } & \multirow[t]{2}{*}{ Mean } \\
\hline & Low & Intermediate & High & \\
\hline \multicolumn{5}{|c|}{ RDM (g plant $\left.{ }^{-1}\right)$} \\
\hline L1 (T) & $9.12 \mathrm{~A}$ & $8.48 \mathrm{~A}$ & $5.69 \mathrm{~A}$ & $7.76 \mathrm{~B}$ \\
\hline L2 (S) & $11.82 \mathrm{~A}$ & $11.02 \mathrm{~A}$ & $6.72 \mathrm{~A}$ & $9.85 \mathrm{~A}$ \\
\hline $\mathrm{L} 3(\mathrm{~T})$ & $9.25 \mathrm{~A}$ & $8.24 \mathrm{~A}$ & $5.50 \mathrm{~A}$ & $8.24 \mathrm{~B}$ \\
\hline L4 (S) & $10.11 \mathrm{~A}$ & $9.99 \mathrm{~A}$ & $9.20 \mathrm{~A}$ & $9.76 \mathrm{~A}$ \\
\hline Mean & $10.07 \mathrm{a}$ & $9.43 \mathrm{a}$ & $6.18 \mathrm{~b}$ & \\
\hline \multicolumn{5}{|c|}{ SDM $\left(\right.$ g plant $\left.^{-1}\right)$} \\
\hline L1 (T) & $11.11 \mathrm{~B}$ & $10.56 \mathrm{~B}$ & $10.75 \mathrm{~A}$ & $10.81 \mathrm{~B}$ \\
\hline L2 (S) & $10.97 \mathrm{~B}$ & $10.89 \mathrm{~B}$ & $11.32 \mathrm{~A}$ & $11.06 \mathrm{~B}$ \\
\hline L3 (T) & $11.23 \mathrm{~B}$ & $10.87 \mathrm{~B}$ & $11.36 \mathrm{~A}$ & $11.15 \mathrm{~B}$ \\
\hline L4 (S) & $12.22 \mathrm{~A}$ & $12.28 \mathrm{~A}$ & $10.64 \mathrm{~A}$ & $11.71 \mathrm{~A}$ \\
\hline Mean & $11.38 \mathrm{a}$ & $11.15 \mathrm{a}$ & $11.02 \mathrm{a}$ & \\
\hline \multicolumn{5}{|c|}{ TDM $\left(\right.$ g plant $\left.^{-1}\right)$} \\
\hline L1 (T) & $6.75 \mathrm{~A}$ & $6.35 \mathrm{~B}$ & $5.50 \mathrm{~A}$ & $6.20 \mathrm{~B}$ \\
\hline L2 (S) & $7.60 \mathrm{~A}$ & $7.30 \mathrm{~A}$ & $6.00 \mathrm{~A}$ & $6.96 \mathrm{~A}$ \\
\hline L3 $(\mathrm{T})$ & $6.85 \mathrm{~A}$ & $6.40 \mathrm{~B}$ & $5.65 \mathrm{~A}$ & $6.30 \mathrm{~B}$ \\
\hline L4 (S) & $7.45 \mathrm{~A}$ & $7.45 \mathrm{~A}$ & $6.60 \mathrm{~A}$ & $7.16 \mathrm{~A}$ \\
\hline Mean & $7.16 \mathrm{a}$ & $6.87 \mathrm{a}$ & $5.93 \mathrm{~b}$ & \\
\hline \multicolumn{5}{|c|}{ RDM/SDM } \\
\hline L1 (T) & $0.81 \mathrm{~A}$ & $0.79 \mathrm{~A}$ & $0.54 \mathrm{~A}$ & $0.71 \mathrm{~A}$ \\
\hline L2 (S) & $1.07 \mathrm{~A}$ & $1.00 \mathrm{~A}$ & $0.60 \mathrm{~A}$ & $0.89 \mathrm{~A}$ \\
\hline L3 (T) & $0.82 \mathrm{~A}$ & $0.75 \mathrm{~A}$ & $0.48 \mathrm{~A}$ & $0.68 \mathrm{~A}$ \\
\hline L4 (S) & $0.82 \mathrm{~A}$ & $0.80 \mathrm{~A}$ & $0.86 \mathrm{~A}$ & $0.83 \mathrm{~A}$ \\
\hline Mean & $0.88 \mathrm{a}$ & $0.84 \mathrm{a}$ & $0.62 \mathrm{~b}$ & \\
\hline
\end{tabular}

${ }^{1}$ Means followed by the same capital letter in vertical and lowercase letter in horizontal did not differ significantly by Scott-Knott test at 5\%; S - drought sensitive, T - drought tolerant.

At low and intermediate saturation levels the tolerant lines (L1 and L3) stood out with higher root length (RL), and similarly the line L1 under high aluminum saturation (Table 4).

At 14 days after seeding (DAS) no difference was observed for root surface area
(SA) under the three levels of saturation (Table 4). On average, tolerant lines (L1 and L3) presented higher SA and the same behavior was observed between the genotypes under the high level of aluminum. No difference was observed for SA at 28 DAS (Table 4). 
TABLE 4. Total root length (RL); root surface area (SA); root volume (RV) of maize genotypes in response to different levels of $\mathrm{Al}$ saturation at 14 and $28 \mathrm{DAS}^{1}$.

\begin{tabular}{|c|c|c|c|c|c|c|c|c|}
\hline \multirow{4}{*}{ 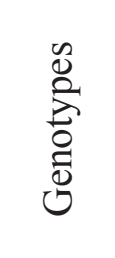 } & \multicolumn{4}{|c|}{ Al level } & \multicolumn{4}{|c|}{ Al level } \\
\hline & Low & Intermediate & High & Mean & Low & Intermediate & High & Mean \\
\hline & \multicolumn{4}{|c|}{$14 \mathrm{DAS}$} & \multicolumn{4}{|c|}{$28 \mathrm{DAS}$} \\
\hline & \multicolumn{8}{|c|}{$\mathrm{RL}\left(\mathrm{cm}\right.$ plant $\left.{ }^{-1}\right)$} \\
\hline L1 (T) & $519.47 \mathrm{~A}$ & $364.19 \mathrm{~A}$ & $571.56 \mathrm{~A}$ & $485.07 \mathrm{~A}$ & $954.95 \mathrm{~A}$ & $842.26 \mathrm{~A}$ & $878.97 \mathrm{~A}$ & $892.06 \mathrm{~A}$ \\
\hline L2 (S) & $354.16 \mathrm{~A}$ & $328.91 \mathrm{~A}$ & $249.80 \mathrm{~B}$ & $310.96 \mathrm{~B}$ & $351.18 \mathrm{~B}$ & $392.68 \mathrm{~B}$ & $582.16 \mathrm{~B}$ & $442.01 \mathrm{~B}$ \\
\hline $\mathrm{L} 3(\mathrm{~T})$ & $422.21 \mathrm{~A}$ & $508.36 \mathrm{~A}$ & $515.60 \mathrm{~A}$ & $482.06 \mathrm{~A}$ & $974.60 \mathrm{~A}$ & $994.73 \mathrm{~A}$ & $774.81 \mathrm{~B}$ & $914.71 \mathrm{~A}$ \\
\hline L4 (S) & $291.83 \mathrm{~A}$ & $401.97 \mathrm{~A}$ & $292.73 \mathrm{~B}$ & $328.85 \mathrm{~B}$ & $668.90 \mathrm{~B}$ & $447.69 \mathrm{~B}$ & $745.04 \mathrm{~B}$ & $620.54 \mathrm{~B}$ \\
\hline \multirow[t]{2}{*}{ Mean } & $396.92 \mathrm{a}$ & $400.86 \mathrm{a}$ & $407.42 \mathrm{a}$ & & $737.40 \mathrm{a}$ & $669.34 \mathrm{a}$ & $745.25 \mathrm{a}$ & \\
\hline & \multicolumn{8}{|c|}{$\mathrm{SA}\left(\mathrm{cm}^{2}\right.$ plant $\left.^{-1}\right)$} \\
\hline $\mathrm{L} 1(\mathrm{~T})$ & $61.90 \mathrm{~A}$ & $46.05 \mathrm{~A}$ & $75.64 \mathrm{~A}$ & $61.20 \mathrm{~A}$ & $125.96 \mathrm{~A}$ & $116.90 \mathrm{~A}$ & $121.98 \mathrm{~A}$ & $121.61 \mathrm{~A}$ \\
\hline L2 (S) & $42.44 \mathrm{~A}$ & $39.55 \mathrm{~A}$ & $37.01 \mathrm{~B}$ & $39.67 \mathrm{~B}$ & $59.09 \mathrm{~A}$ & $50.17 \mathrm{~A}$ & $84.59 \mathrm{~A}$ & $64.61 \mathrm{~A}$ \\
\hline L3 (T) & $54.30 \mathrm{~A}$ & $67.09 \mathrm{~A}$ & $79.67 \mathrm{~A}$ & $67.02 \mathrm{~A}$ & $131.64 \mathrm{~A}$ & $140.68 \mathrm{~A}$ & $112.16 \mathrm{~A}$ & $128.16 \mathrm{~A}$ \\
\hline L4 (S) & $37.53 \mathrm{~A}$ & $54.44 \mathrm{~A}$ & $43.24 \mathrm{~B}$ & $45.07 \mathrm{~B}$ & $164.25 \mathrm{~A}$ & $60.95 \mathrm{~A}$ & $107.04 \mathrm{~A}$ & $110.74 \mathrm{~A}$ \\
\hline \multirow[t]{2}{*}{ Mean } & $49.04 \mathrm{a}$ & $51.78 \mathrm{a}$ & $58.89 \mathrm{a}$ & & $120.23 \mathrm{a}$ & $92.17 \mathrm{a}$ & $106.44 \mathrm{a}$ & \\
\hline & \multicolumn{8}{|c|}{$\mathrm{RV}\left(\mathrm{cm}^{3}\right.$ plant $\left.^{-1}\right)$} \\
\hline $\mathrm{L} 1(\mathrm{~T})$ & $0.58 \mathrm{~A}$ & $0.46 \mathrm{~A}$ & $0.79 \mathrm{~A}$ & $0.62 \mathrm{~A}$ & $1.32 \mathrm{~A}$ & $1.30 \mathrm{~A}$ & $1.36 \mathrm{~A}$ & $1.32 \mathrm{~A}$ \\
\hline L2 (S) & $0.40 \mathrm{~A}$ & $0.37 \mathrm{~A}$ & $0.43 \mathrm{~B}$ & $0.40 \mathrm{~B}$ & $0.79 \mathrm{~A}$ & $0.51 \mathrm{~A}$ & $0.98 \mathrm{~A}$ & $0.76 \mathrm{~A}$ \\
\hline L3 (T) & $0.55 \mathrm{~A}$ & $0.70 \mathrm{~A}$ & $0.98 \mathrm{~A}$ & $0.74 \mathrm{~A}$ & $1.42 \mathrm{~A}$ & $1.58 \mathrm{~A}$ & $1.29 \mathrm{~A}$ & $1.43 \mathrm{~A}$ \\
\hline L4 (S) & $0.38 \mathrm{~A}$ & $0.59 \mathrm{~A}$ & $0.51 \mathrm{~B}$ & $0.49 \mathrm{~B}$ & $1.85 \mathrm{~A}$ & $0.66 \mathrm{~A}$ & $1.22 \mathrm{~A}$ & $1.24 \mathrm{~A}$ \\
\hline Mean & $0.48 \mathrm{~b}$ & $0.53 \mathrm{~b}$ & $0.68 \mathrm{a}$ & & $1.35 \mathrm{a}$ & $1.01 \mathrm{a}$ & $1.21 \mathrm{a}$ & \\
\hline
\end{tabular}

${ }^{1}$ Means followed by the same capital letter in vertical and lowercase letter in horizontal did not differ significantly by Scott-Knott test at 5\%; S - drought sensitive, T - drought tolerant.

Increase in root volume (RV) occurred under the high aluminum saturation level compared to the low and intermediate levels, at 14 days after sowing (DAS) (Table 4). Concerning mean of genotypes, tolerant lines (L1 and L3) presented higher volume which could be also verified for lines under high saturation level. Similarly to root surface area at 28 DAS, no significant difference was observed for root volume (RV) (Table 4).

The characterization of root morphology through digital images with the WinRhizo software has shown good results in studies on flooding 
(Henshaw et al., 2007), drought (Hund et al., 2009), phosphorus deficiency (Magalhães et al., 2011) and nitrogen deficiency (Soares et al., 2009). In the present study, good discrimination of roots was achieved.

In general, drought-tolerant lines presented the best results for the traits total length (TL), root surface area (SA) and root volume (RV), especially at 14 DAS (Tables 4). As for water stress (Hund et al., 2009) as for aluminum stress a well-developed root system is important for tolerance to these stresses. Imada et al. (2008) affirm that root surface area is the trait more related to nutrients absorption. Increase of root volume in cereals can cause a greater efficiency in absorption of nutrients. However, Costa et al. (2002) affirm that this condition is true only when the concentration of nutrients is the same in all root surfaces.

Thus, the different behavior of drought tolerant lines concerning these characteristics (TL, SA and RV) suggests that the genetic breeding for drought tolerance is related to aluminum tolerance, since the inhibition of the root system growth is the first symptom observed in plants subjected to toxic levels of aluminum (Horst et al., 2010). Comin et al. (2006), studying aluminum toxicity in maize observed that tolerant genotypes presented greater root system than sensitive. Martins et al. (1999), evaluating two inbred maize lines considered sensitive, one line and one open-pollinated variety aluminum tolerant, observed that the tolerant materials presented the highest values for the phenotypic indices relative length of seminal root and net length of seminal root.

Roots grown on high level of aluminum saturation had increased the mean root diameter (MRD) compared to the other levels, but only at 14 days after sowing (Table 5). Also at 14 DAS, in mean of genotypes the lines L3 (tolerant) and L4 (sensitive) presented higher MRD. Between lines, difference occurred only under the high saturation level, with the L1 tolerant line showing a smaller diameter (Table 5).

Thick roots under high aluminum level evaluated at 14 DAS confirmed explanations that roots of plants grown in the presence of toxic levels of Al become short, thick and did not develop lateral roots, increasing susceptibility to drought and reducing the absorption of nutrients from soil solution (Bona et al., 1991; Kochian et al., 2004; Kochian et al., 2005).

At 14 and 28 days after seeding, the mean of genotypes at the three levels of aluminum saturation for specific root length (SRL) and root length/shoot dry mass ratio presented the highest values for $\mathrm{L} 1$ and L3 tolerant genotypes (Figure 1).

It was observed in this study that drought tolerant lines presented the highest values for total root length/shoot dry mass ratio (TRL/SDM), demonstrating that these material spend most of their photoassimilates in root production. This would be a desirable characteristic because materials with greater root system would be more efficient in acquiring nutrients and water (Ryser, 2006). Similarly, drought tolerant lines presented the highest values for specific root length (SRL). It is known that a higher SRL results in a higher exploration and acquisition of water and nutrients of soil per unit of carbon invested (Bouma et al., 2001).

One can observe in Table 6 that roots of the very thin group were the main contributors to total root length (diameter inferior to $0.5 \mathrm{~mm}$ ). When evaluated the length of very thin roots (VTRL) no difference was observed at 14 days after seeding under the three saturation levels (Table 6). 
TABLE 5. Mean root diameter (MRD) of maize genotypes in response to different levels of Al saturation at 14 and 28 DAS.

\begin{tabular}{lllll}
\hline \multirow{2}{*}{ Genotypes } & \multicolumn{4}{c}{ MRD $(\mathrm{mm} \text { plant })^{-1}$} \\
\cline { 2 - 5 } & Low-Al & Intermediate-Al & High-Al & Mean \\
\hline L1 (T) & $0.38 \mathrm{~A}$ & $0.40 \mathrm{~A}$ & $0.42 \mathrm{~A}$ & $0.40 \mathrm{~B}$ \\
L2 (S) & $0.38 \mathrm{~A}$ & $0.37 \mathrm{~A}$ & $0.47 \mathrm{~B}$ & $0.41 \mathrm{~B}$ \\
L3 (T) & $0.41 \mathrm{~A}$ & $0.42 \mathrm{~A}$ & $0.49 \mathrm{~B}$ & $0.44 \mathrm{~A}$ \\
L4 (S) & $0.41 \mathrm{~A}$ & $0.42 \mathrm{~A}$ & $0.47 \mathrm{~B}$ & $0.43 \mathrm{~A}$ \\
\hline Mean & $0.39 \mathrm{~b}$ & $0.40 \mathrm{~b}$ & $0.46 \mathrm{a}$ & \\
\hline & & & \\
\hline L1 (T) & $0.42 \mathrm{~A}$ & $0.43 \mathrm{~A}$ DAS & $0.43 \mathrm{~A}$ & $0.43 \mathrm{~A}$ \\
L2 (S) & $0.54 \mathrm{~A}$ & $0.40 \mathrm{~A}$ & $0.48 \mathrm{~A}$ & $0.44 \mathrm{~A}$ \\
L3 (T) & $0.43 \mathrm{~A}$ & $0.45 \mathrm{~A}$ & $0.46 \mathrm{~A}$ & $0.61 \mathrm{~A}$ \\
L4 (S) & $0.92 \mathrm{~A}$ & $0.43 \mathrm{~A}$ & $0.46 \mathrm{~A}$ & \\
\hline Mean & $0.58 \mathrm{a}$ & $0.43 \mathrm{a}$ & $0.46 \mathrm{a}$ & \\
\hline
\end{tabular}

${ }^{1}$ Means followed by the same capital letter in vertical and lowercase letter in horizontal did not differ significantly by Scott-Knott test at 5\%; S - drought sensitive, T - drought tolerant.

VTRL was significantly different in mean of genotypes and between genotypes at the higher level of Al saturation, with the highest values for tolerant lines (Table 6). At 28 DAS the behavior was similar, however a greater length of very thin roots (VTRL) was found for tolerant lines under low level of $\mathrm{Al}$ saturation instead of high (Table 6).

No difference occurred among levels of $\mathrm{Al}$ saturation for thin roots length (TRL) at 14 days after sowing (DAS) (Table 6). In mean of genotypes, tolerant lines stood out with higher TRL. Concerning the genotypes only under the high saturation level, significant differences occurred between lines. In this condition, tolerant again stood out showing higher thin roots length (TRL). For the evaluation of TRL at 28 DAS no significant difference occurred (Table 6).

Thick roots length (THRL) presented significant differences only at 14 DAS (excepting between means of levels of aluminum saturation). Between genotypes under low level of Al saturation, the L1 tolerant line presented higher values for THRL. At intermediate level, the lines L3 and L4 (tolerant and sensitive, respectively) showed higher THRL and at the high saturation the highest lengths were found for lines L1 and L3 (tolerant) (Table 6).

The present drought-tolerant lines presented greater amount of thin roots than sensitive, under high levels of aluminum saturation. The efficiency in absorbing nutrients such as aluminum has a direct relationship with length and average root diameter (especially thin roots), because these morphological attributes of the root system directly affect the surface of nutrients absorption (Fitter, 2002; Zobel et al., 2007). 


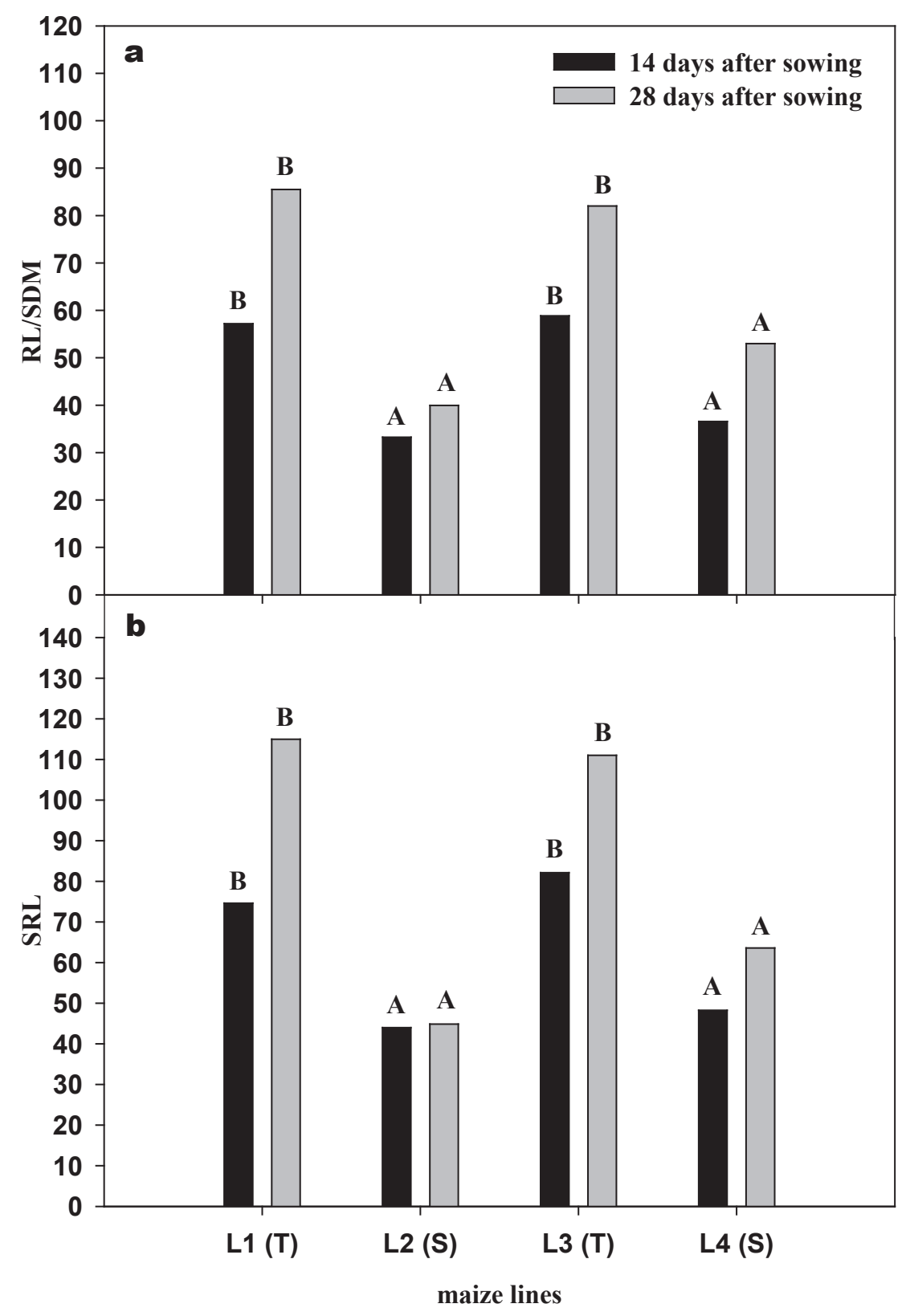

FIGURE 1. Total root length/shoot dry mass ratio (RL/SDM) (a) and specific root length (SRL, total root length/root dry mass) (b), mean of genotypes at the three levels of Al saturation at 14 and 28 DAS. Bars with the same capital letter did not differ significantly by Scott-Knott test at 5\% among genotypes. S - drought sensitive, $\mathrm{T}$ - drought tolerant. 
Regarding evaluation of roots of genotypes contrasting to drought resistance under variable levels of nutrients in the soil, similar results were observed by Cantão et al. (2008). These authors evaluated maize lines contrasting to drought tolerance under different levels of phosphorus and reported changes in root morphology as a function of the levels of phosphorus and the genetic background of the evaluated lines.

TABLE 6. Root length in diameter class, very thin roots (VTRL, Ø inferior to $0.5 \mathrm{~mm}$ ); thin roots (TRL, $>0.5$ $\varnothing<2.0 \mathrm{~mm}$ ); thick roots (THRL, $\varnothing>2.0 \mathrm{~mm}$ ) of seedlings of maize genotype in response to different levels of Al saturation at 14 and 28 DAS.

\begin{tabular}{|c|c|c|c|c|c|c|c|c|}
\hline \multirow{4}{*}{$\begin{array}{l}\text { 0. } \\
\text { 0. } \\
0 \\
0 \\
0 \\
0\end{array}$} & \multicolumn{4}{|c|}{ Al level } & \multicolumn{4}{|l|}{ Al level } \\
\hline & Low & Intermediate & High & Mean & Low & Intermediate & High & Mean \\
\hline & \multicolumn{8}{|c|}{ VTRL $\left(\mathrm{cm} \text { plant }{ }^{-1}\right)^{1}$} \\
\hline & \multicolumn{4}{|c|}{14 DAS } & \multicolumn{4}{|c|}{28 DAS } \\
\hline $\mathrm{L} 1(\mathrm{~T})$ & $409.94 \mathrm{~A}$ & $270.38 \mathrm{~A}$ & $441.979 \mathrm{~A}$ & $374.10 \mathrm{~A}$ & $898.58 \mathrm{~A}$ & $626.33 \mathrm{~A}$ & $653.54 \mathrm{~A}$ & $726.15 \mathrm{~A}$ \\
\hline L2 (S) & $279.34 \mathrm{~A}$ & $301.98 \mathrm{~A}$ & $160.780 \mathrm{~B}$ & $247.37 \mathrm{~B}$ & $212.41 \mathrm{~B}$ & $274.85 \mathrm{~A}$ & $390.13 \mathrm{~A}$ & $292.46 \mathrm{~B}$ \\
\hline L3 (T) & $318.09 \mathrm{~A}$ & $383.07 \mathrm{~A}$ & $354.544 \mathrm{~A}$ & $351.90 \mathrm{~A}$ & $712.96 \mathrm{~A}$ & $686.74 \mathrm{~A}$ & $532.58 \mathrm{~A}$ & $644.09 \mathrm{~A}$ \\
\hline L4 (S) & $211.65 \mathrm{~A}$ & $287.96 \mathrm{~A}$ & $202.416 \mathrm{~B}$ & $234.01 \mathrm{~B}$ & $469.92 \mathrm{~B}$ & $329.83 \mathrm{~A}$ & $529.40 \mathrm{~A}$ & $443.05 \mathrm{~B}$ \\
\hline \multirow[t]{2}{*}{ Mean } & $304.74 \mathrm{a}$ & $310.85 \mathrm{a}$ & $289.93 \mathrm{a}$ & & $573.47 \mathrm{a}$ & $479.44 \mathrm{a}$ & $526.41 \mathrm{a}$ & \\
\hline & \multicolumn{8}{|c|}{ TRL $\left(\mathrm{cm} \mathrm{plant}^{-1}\right)^{1}$} \\
\hline $\mathrm{L} 1(\mathrm{~T})$ & $105.14 \mathrm{~A}$ & $91.11 \mathrm{~A}$ & $124.91 \mathrm{~A}$ & $107.05 \mathrm{~A}$ & $217.85 \mathrm{~A}$ & $207.24 \mathrm{~A}$ & $218.20 \mathrm{~A}$ & $214.43 \mathrm{~A}$ \\
\hline L2 (S) & $72.82 \mathrm{~A}$ & $76.33 \mathrm{~A}$ & $86.67 \mathrm{~B}$ & $78.61 \mathrm{~B}$ & $131.82 \mathrm{~A}$ & $115.36 \mathrm{~A}$ & $187.65 \mathrm{~A}$ & $144.94 \mathrm{~A}$ \\
\hline L3 $(\mathrm{T})$ & $101.47 \mathrm{~A}$ & $120.66 \mathrm{~A}$ & $154.89 \mathrm{~A}$ & $125.67 \mathrm{~A}$ & $255.17 \mathrm{~A}$ & $255.17 \mathrm{~A}$ & $236.24 \mathrm{~A}$ & $264.00 \mathrm{~A}$ \\
\hline L4 (S) & $77.77 \mathrm{~A}$ & $109.72 \mathrm{~A}$ & $88.28 \mathrm{~B}$ & $91.93 \mathrm{~B}$ & $193.78 \mathrm{~A}$ & $112.82 \mathrm{~A}$ & $209.98 \mathrm{~A}$ & $172.20 \mathrm{~A}$ \\
\hline \multirow[t]{2}{*}{ Mean } & $89.30 \mathrm{a}$ & $99.46 \mathrm{a}$ & 113.69 a & & $199.65 \mathrm{a}$ & $184.00 \mathrm{a}$ & $213.02 \mathrm{a}$ & \\
\hline & \multicolumn{8}{|c|}{ THRL $\left(\mathrm{cm} \mathrm{plant}^{-1}\right)^{1}$} \\
\hline $\mathrm{L} 1(\mathrm{~T})$ & $3.78 \mathrm{~A}$ & $2.16 \mathrm{~B}$ & $4.07 \mathrm{~A}$ & $3.34 \mathrm{~A}$ & $7.27 \mathrm{~A}$ & $7.92 \mathrm{~A}$ & $6.48 \mathrm{~A}$ & $7.22 \mathrm{~A}$ \\
\hline L2 (S) & $1.70 \mathrm{~B}$ & $2.26 \mathrm{~B}$ & $2.19 \mathrm{~B}$ & $2.05 \mathrm{~A}$ & $6.53 \mathrm{~A}$ & $1.94 \mathrm{~A}$ & $3.95 \mathrm{~A}$ & $4.14 \mathrm{~A}$ \\
\hline L3 (T) & $2.12 \mathrm{~B}$ & $4.07 \mathrm{~A}$ & $5.64 \mathrm{~A}$ & $3.94 \mathrm{~A}$ & $5.11 \mathrm{~A}$ & $5.98 \mathrm{~A}$ & $5.30 \mathrm{~A}$ & $5.46 \mathrm{~A}$ \\
\hline L4 (S) & $1.97 \mathrm{~B}$ & $3.70 \mathrm{~A}$ & $1.66 \mathrm{~B}$ & $2.44 \mathrm{~A}$ & $4.55 \mathrm{~A}$ & $4.62 \mathrm{~A}$ & $4.91 \mathrm{~A}$ & $4.69 \mathrm{~A}$ \\
\hline Mean & $2.39 \mathrm{a}$ & $3.05 \mathrm{a}$ & $3.34 \mathrm{a}$ & & $5.86 \mathrm{a}$ & $5.12 \mathrm{a}$ & $5.16 \mathrm{a}$ & \\
\hline
\end{tabular}

${ }^{1}$ Means followed by the same capital letter in vertical and lowercase letter in horizontal did not differ significantly by Scott-Knott test at 5\%; S - drought sensitive, T - drought tolerant. 


\section{Conclusions}

Drought-sensitive lines stood out regarding dry mass attributes. Lines pre-selected for drought tolerance presented more developed root system compared to the sensitive under high levels of Al saturation, indicating that these materials are indirectly selected for tolerance to aluminum stress, when selected for higher drought tolerance.

\section{References}

ALI, S.; ZENG, F.; QIU, L.; ZHANG, G. The effect of chromium and aluminum on growth, root morphology, photosynthetic parameters and transpiration of the two barley cultivars. Biologia Plantarum, Prague, v. 55, p. 291-296, 2011.

BOHM, W. Methods of studying root systems. New York: Springer-Verlag, 1979. 188 p.

BONA, L.; MATUZ, J.; PURNHAUSER, L. Aluminium tolerance of Triticum aestivum L. populations related to plant-induced $\mathrm{pH}$ changes of nutrient solution. In: WRIGHT, R. J.; BALIGAR, V. C.; MUMMANN, R. P. (Ed.) Plant-soil interactions at low pH. Netherlands: Kluwer, 1991. p. 1057-1062.

BOUMA, T. J.; NIELSEN, K. L.; VAN HAL, J.; KOUTSTAAL, B. Root system topology and diameter distribution of species from habitats differing in inundation frequency. Journal Ecology, Oxford, v. 15, p. 360-369, 2001.

BOUMA, T. J.; NIELSON, K. L.; KOUTSTAAL, B. A. S. Sample preparation and scanning protocol for computerized analysis of root length and diameter. Plant and Soil, Dordrecht, v. 218, p. 185-196, 2000. CANÇADO, G. M. A.; PARENTONI, S. N.; BORÉM, A.; LOPES, M. A. Avaliação de nove linhagens de milho em cruzamentos dialélicos quanto à tolerância ao alumínio. Pesquisa Agropecuária Brasileira, Brasília, DF, v. 37, p. 471-478, 2002.

CANTÃO, F. R. O.; DURÃES, F. O. M.; OLIVEIRA, A. C.; SOARES, A. M.; MAGAlHÃES, P. C. Morphological attributes of root system of maize genotypes contrasting in drought tolerance due to phosphorus stress. Revista Brasileira de Milho e Sorgo, Sete Lagoas, v. 7, p. 113-127, 2008.

COSTA, C.; DWYER, L. M.; ZHOU, X.; DUTILLEUL, P.; HAMEL, C.; REID, L.M.; SMITH, D. L. Root morphology of contrasting maize genotypes. Agronomy Journal, Madison, v. 94, p. 96-101, 2002. COMIN, J. J.; BRLOY, J.; HALLAIRE, V.; ZANETTE, F.; MILLER, P. R. M. Effects of aluminium on the adventitious root system, aerial biomass and grain yield of maize grown in the field and in a rhizotron. Experimental Agriculture, Cambridge, v. 42, p. 351366, 2006.

DONCHEVA, S.; AMENOS, M.; POSCHENRIEDER, C.; BARCELO, J. Root cell patterning: a primary target for aluminium toxicity in maize. Journal of Experimental Botany, Oxford, v. 56, p. 1213-1220, 2005.

FAN, X-W.; LI, F-M.; SONGA, L.; XIONGA, Y-C.; AN, L-Z.; JIA, Y.; FANG, X-W. Defense strategy of old and modern spring wheat varieties during soil drying. Physiologia Plantarum, Heidelberg, v.136, p. 310323, 2009.

FARIAS, E. S. T.; PINTRO, J. C.; SILVA, M. A. G.; MUNIZ, A. S.; MARCHETTI, M. E.; NOLLA, A.; PELLISSON, N. Aluminum toxicity in corn plants cultivated with low and high ionic strength nutrient solutions. Journal of Plant Nutrition, New York, v. 34, p. 465-475, 2011.

FITTER, A. H. Characteristics and functions of root 
systems. In: WEISEL, Y.; ESHEL, A.; KAFKAFI, U. (Ed.). Plant roots: the hidden half. 3. ed. New York: Marcel Dekker, 2002. p. 15-22.

HALING, R. E.; SIMPSON, R. J.; DELHAIZE, E.; HOCKING, P. J.; RICHARDSON, A. E. Effect of lime on root growth, morphology and the rhizosheath of cereal seedlings growing in an acid soil. Plant and Soil, Dordrecht, v. 327, p.199-212, 2010.

HENSHAW, T. L.; GILBERT, R. A.; SCHOLBERG, J. M. S.; SINCLAIR, T. R. Soya bean (Glycine max L. Merr.) genotype response to early-season flooding: I. Root and nodule development. Journal of Agronomy and Crop Science, Lexington, v. 193, p.177-188, 2007.

HORN, D.; ERNANI, P. R.; SANGOI, L.; SCHWATZER, C.; CASSOL, P. C. Parâmetros cinéticos e morfológicos da absorção de nutrientes em cultivares de milho com variabilidade genética contrastante. Revista Brasileira de Ciência do Solo, Campinas, v. 30, p. 77-85, 2006.

HORST, W. J.; WANG, Y.; ETICHA, D. The role of the root apoplast in aluminium-induced inhibition of root elongation and in aluminium resistance of plants: a review. Annals of Botany, Oxford, v. 106, p. 185-197, 2010.

HUND, A.; RUYA, N.; LIEDGENS, M. Rooting depth and water use efficiency of tropical maize inbred lines, differing in drought tolerance. Plant and Soil, Dordrecht, v. 318, p.311-325, 2009.

IMADA, S.; YAMANAKA, N.; TAMAI, S. Water table depth effects Populus alba fine root growth and whole plant biomass. Functional Ecology, London, v. 22, p. 1018-1026, 2008.

KOCHIAN, L V.; HOEKENGA, O. A.; PINEROS, M. A. How do crop plants tolerate acid soils? Mechanisms of aluminum tolerance and phosphorous efficiency. Annual Review Plant Biology, Palo Alto, v. 55, p.
459-493, 2004.

KOCHIAN ,L. V.; PINEROS, M. A.; HOEKENGA, O. A. The physiology, genetics and molecular biology of plant aluminum resistance and toxicity. Plant and Soil, Dordrecht, v. 274, p.175-195, 2005.

LI; Y.; SPERRY; J. S.; SHAO, M. Hydraulic conductance and vulnerability to cavitation in corn (Zea mays L.) hybrids of differing drought resistance. Environmental and Experimental Botany, Oxford, v. 66, p. 341-346, 2009.

MAGAlhães, P. C.; SOUZA, T. C.; CANTÃO, F. R. O. Early evaluation of root morphology of maize genotypes under phosphorus deficiency. Plant Soil and Environment, Praha, v. 57, p.135-138, 2011.

MARTINS, P. R.; PARENTONI, S. N.; LOPES, M. A.; PAIVA E. Eficiência de índices fenotípicos de comprimento de raiz seminal na avaliação de plantas individuais de milho quanto à tolerância ao alumínio. Pesquisa Agropecuária Brasileira, Brasília, DF, v. 34, p. 1897-1904, 1999.

MIHAILOVIC, N.; DRAZIC, G.; VUCINIC, Z. Effects of aluminium on photosynthetic performance in Al-sensitive and Al-tolerant maize inbred lines. Photosynthetica, Prague, v. 46, p. 476-480, 2008.

OKIYO, T.; GUDU, S.; KIPLAGAT, O.; OWUOCHE, J. Combining drought and aluminium toxicity tolerance to improve sorghum productivity. African

Crop Science Journal, Kampala, v.18, p.147-154, 2010.

PEIXOTO, P. H. P.; DA MATTA, F. M.; CAMBRAIA, J. Responses of the photosynthetic apparatus to aluminum stress in two sorghum cultivars. Journal of Plant Nutrition, New York, v. 25, p. 821-832, 2002. RYSER, P. The mysterious root length. Plant and Soil, Dordrecht, v. 286, p. 1-6, 2006.

SANTOS, H. G.; JACOMINE, P. K. T.; ANJOS, L. H. C.; 
OLIVEIRA, V. A.; OLIVEIRA, J. B.; COELHO, M. R.; LUMBRERAS, J. F.; CUNHA, T. J. F. Sistema brasileiro de classificação de solos. 2 ed. Rio de Janeiro: Embrapa Solos, 2006. 306 p.

SOARES, M. O.; MARRIEL, I. E.; MAGALHÃES, P. C.; Guimarães, L. J. M.; CANTÃO, F. R. O.; ROCHA, M. C.; CARVALHO JUNIOR, G. A.; MIRANDA, G. V. Discrimination of maize lines as to nitrogen utilization through evaluation of root system characteristics. Revista Brasileira de Milho e Sorgo, Sete Lagoas, v. 8, p. 93-103, 2009.

TAMÁS, L.; HITTOVÁ, J.; MISTRÍK, I.; SIMONOVICOVÁ, M.; SIROKÁ, B. Aluminiuminduced drought and oxidative stress in barley roots. Journal of Plant Physiology, Collingwood, v. 163, p. 781-784, 2006.

TRACHSEL, S.; KAEPPLER, S. M.; BROWN, K. B.; LYNCH, J. P. Shovelomics: high throughput phenotyping of maize (Zea mays L.) root architecture in the field. Plant and Soil, Dordrecht, v. 341, p. 75$87,2011$.

TUBEROSA, R.; SALVI, S.; GIULIANI, S.; SANGUINETI, M. C.; BELLOTTI, M.; CONTI, S.;
LANDI, P. Genome-wide approaches to investigate and improve maize response to drought. Crop Science, Madison, v. 47, p. 120-141, 2007.

VAMERALI, T.; SACCOMANI, M.; BONA, S.; MOSCA, G.; GUARISE, M.; GANIS, A. A comparison of root characteristics in relation to nutrient and water stress in two maize hybrids. Plant and Soil, Dordrecht, v. 255, p. 157-167, 2003.

WELCKER, C.; BOUSSUGE, B.; BENCIVENNI, C.; RIBAUT, M.; TARDIEU, F. Are source and sink strengths genetically linked in maize plants subjected to water deficit? A QTL study of the responses of leaf growth and of Anthesis-Silking Interval to water deficit. Journal of Experimental Botany, Oxford, v. 58, p. 339-349, 2007.

ZOBEL, R. W.; KINRAIDE, T. B.; BALIGAR, V. C. Fine root diameters can change in response to changes in nutrient concentrations. Plant and Soil, Dordrecht, v. 297, p. 243-254, 2007.

YU, H. N.; LIU, P.; WANG, Z. Y.; CHEN, W. R.; XU, G. D. The effect of aluminum treatments on the root growth and cell ultrastructure of two soybean genotypes. Crop Protection, Surrey, v. 30, p. 323-328, 2011. 